\title{
National Budget and Debt as Measures of Public Sector Performance: Empirical Evidence from Nigeria
}

\author{
Onalo Ugbede, Mohd Lizam \& Ahmad Kaseri \\ Faculty of Technology Management \\ Universiti Tun Hussein Onn Malaysia, 86400 Batu Pahat, Johor, Malaysia \\ E-mail: ugbesonas@yahoo.com or ugbedeonalo@yahoo.com
}

Received: June 24, 2013

Accepted: August 14, 2013

Published: December 1, 2013

doi:10.5296/ajfa.v5i2.3896

URL: http://dx.doi.org/10.5296/ajfa.v5i2.3896

\begin{abstract}
Changing the bureaucratic culture of public sector into one that stresses client service and achievement of results, require public sector to clearly define its objectives and priorities as well as assessing its performance against well-defined benchmarks. The objective of this study is to empirically investigate the relationship between national budget and debt as measures of public sector performance. The data for the study were basically secondary data about Nigeria government as an emerging economy for the period 1960-2010. The data so collected were subjected to regression analysis, with budget performance as the independent variable and domestic, external and national debt as dependent variables. Augmented Dickey-Fuller Tests equation was employed to perform unit root tests for stationary and cointegration tests. The findings show that there is significant relationship between budget performance and domestic, external and national debt and these are appropriate and adequate in measuring public sector. The results also indicate that the poorer the budget performance the more the burden of national debt and its attendant cost, resulting into poor public sector performance and national underdevelopment. It is recommended that government should as a matter of transparent accountability prepare budget on accrual basis and put in place structures and mechanisms that will ensure the enactment of federal law making provisions for the amount that the government can borrow and the debt ceiling, which can only be increased with a vote by National Assembly.
\end{abstract}

Keywords: Public sector, Performance measurement, Budget performance, National debt, Surplus budget, Deficit budget 


\section{Introduction}

The concept of performance encompasses the efficiency of a project or activity - the ability to undertake an activity at the minimum cost possible. It also includes effectiveness - whether the objectives set for the activity are being achieved (Mackay, 1998). Performance measurement is the comparison between plans and actuals and it is a valuable exercise which provides an opportunity and a framework for asking fundamental questions such as: What are we trying to achieve? What does "success" look like? How will we know if or when we have achieved it?

In response to the global financial crisis, in 2009, IFAC recommended to G20 that governments, like companies, need timely and accurate financial information to monitor and manage their performance. Traditionally, companies' performances are measured using details on their profit and loss account, including the balance sheet. Contrary, government performance is evaluated based on key fiscal and monetary indicators and objectives, which include general economic growth, price stability and inflation rate, employment of resources, income redistribution, gross domestic product (GDP), per capita income, standard of living, exchange rate, employment rate, and debt burden among others.

The public sectors of different countries are shaped by many factors, but they share common challenges. Those challenges make public sector performance management more complex than it is in the private sector. The generally simpler environment of the private sector and its efficient evolution of best practice allow companies to benefit from tools and insights that are the envy of managers in the public sector (Louise, 2011). In the same vein, it can be assumed that performance is also a dynamic concept that varies across geographical as well as scholarly "schools of thought". Meaning that, what is defined as performance and its crucial elements changes and differs depending on time and space. Thus, though it is the most popular concepts in current public management theory and practice, public sector performance is an ambiguous, multi-dimensional, and complex concept (Lukas and John, 2009). Obviously, performance in the public domain is an elusive concept (Stewart \& Walsh, 1994) and therefore difficult to define and measure (Lukas \& John, 2009) because "stakeholders often disagree about which elements of performance are most important, and some elements are difficult to measure [... and because] tinkering with agency performance also has strong political implications" Brewer \& Selden (2000).

Though no public sector can afford to overlook the importance of clearly defining its objectives and priorities as well as assessing performance against well-defined benchmarks, there exist many types of public sector performance evaluation tools including on-going monitoring and performance information; project and program evaluation-ex ante, on-going/formative and ex post/summative; performance (or value-for-money) audits; financial auditing among others. For the fact that measurement findings can be an important input for government decision-making and prioritization, particularly in the budget process, budget performance can equally be employed as an appropriate base to measure the performance of public sector (Mackay, 1998). Therefore, with the New Public Management (NPM) movement in general and for the fact that since the late 1980 s, performance 
measurement, in particular, have been offered as approaches to help governments reduce their annual budgetary deficits, lower their accumulated debt and improve service delivery (IPAC), this study seek to investigate the relationship between national budget performance and national debt as measures of public sector performance of an emerging economy like Nigeria.

This study is divided into the following sections. Section one is the introduction. Section two discusses related literatures on public sector, performance measurement, usefulness of public sector performance measurement results, the budget as a performance indicator, budget performance, national debt and budget performance, constraints of performance measurement of public sector and Nigeria country profile. Section three focuses on the methodology. Section four is centred on data presentation, analysis, interpretation of results and lessons for past and present Nigerian administration. Section five is all about conclusions and possible recommendations.

\section{Review of Related Literature}

\subsection{Public Sector}

The importance of the public sector is an indisputable social and economic reality throughout the world (Messaoud, 1999). This is because only the public sector can effectively and efficiently carry out certain functions and indeed only national governments can assume the responsibilities that affects the state as a whole (Natural Resources Management and Environment Department, 2003). The public sector sometimes referred to as the state sector or the government sector, is a part of the state that deals with either the production, ownership, sale, provision, delivery and allocation of goods and services by and for the government or its citizens, whether national, regional or local/municipal (Mayhew, 2009). Examples of public sector activity among others include delivering social security, administering urban planning and organizing national defence.

Messaoud (1999) defines public sector as all market and non-market activities which at each institutional level are controlled and mainly financed by public authority. It is composed of a general government sector and a public corporation sector. It is the part of the economy concerned with providing basic government services. Consistent with SNA 93, he further diagrammatically gave the decomposition of public sector as presented below. Thus, the general government is made up of all the government units, social security funds and non-profit non-market public or private institutions which are controlled and mainly financed by public authority. On the other hand, the public corporation sector comprises all of the intuitional units which produce for the market and are controlled and mainly financed by public authority. 


\section{Public Sector}
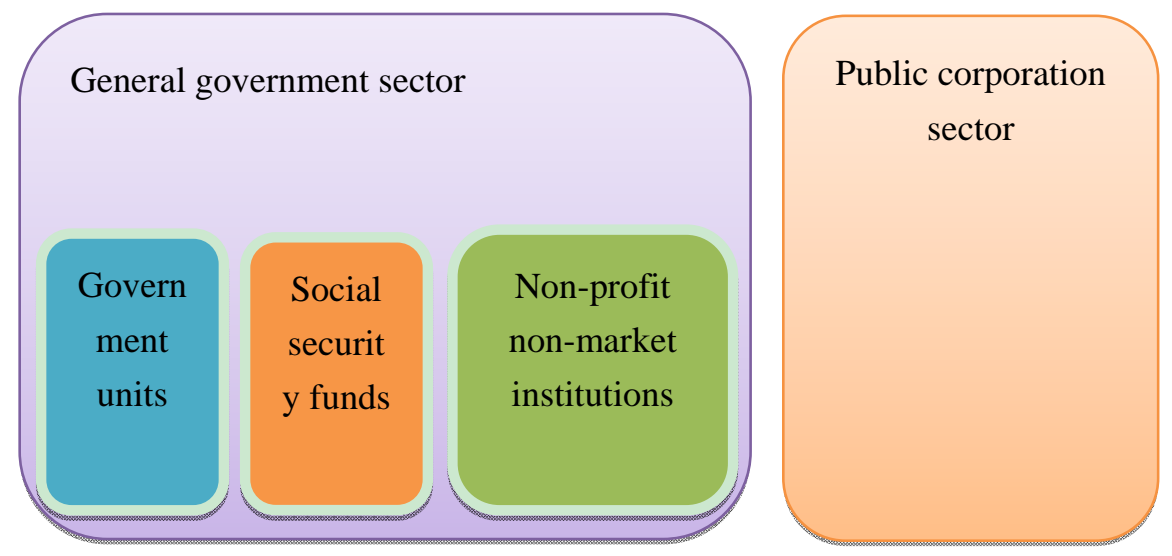

\section{Non-Market institutions}

Market institutions

Source: Messaoud (1999)

It is impossible to discuss the 'global' public sector, as there are so many variations in the scope and shape of public sectors in the 196 countries of the world (Louise, 2011). The public sector in any country is shaped by a combination of various factors, including its economic performance, political philosophy, extent of involvement of external agencies (e.g. aid agencies) and demand from its population for services and infrastructure. However, in most countries the public sector includes such services as the police, military, public roads, public transit, primary education and health care for the poor. It is worthy to note that though the major source of revenue to the public sector is taxation, the public sector might provide services that non-payer cannot be excluded from (such as street lighting), services which benefit all of society rather than just the individual who uses the services (such as public education), and service that encourage equal opportunity.

\subsection{What is Performance Measurement?}

The Institute of Public Administration of Canada (IPAC) posits that performance measurement is an on-going process of ascertaining how well, or how poorly, a government program is being provided. It involves the continuous collection of data on progress made towards achieving the program's pre-established objectives. Performance indicators, or measures, are developed as standards for assessing the extent to which these objectives are achieved. 
To understand clearly the concept of performance measurements IPAC deemed it necessary to distinguish performance measurement from several related concepts. First, the terms performance measurement and performance management are often used interchangeably. However, performance management is a broader term that includes not only performance measurement but also the determination of the appropriate level of performance, the reporting of performance information, and the use of that information to assess the actual level of performance against the desired level. Second performance measurement is often confused with program evaluation, which is an in- depth study conducted on a periodic, rather than an on-going, basis to determine, in the light of current conditions, whether the objectives of a program are still appropriate, whether it is properly designed, and whether it is achieving adequate results. Performance measures are a valuable input into a program evaluation.

Finally, performance measurement is sometimes mistaken for performance evaluation (or performance appraisal), which is a concept associated with human resource management that refers to the systematic collection and analysis of data on the performance of an employee over time.

\subsection{Why Measure Performance?}

IPAC affirmed that the current focus on performance measurement in the public sector has been significantly influenced by the New Public Management (NPM) movement, which, following private sector practice, places heavy emphasis on managing for results. Behn (2003) identified eight purposes for which public managers have for measuring performance as tabulated below:

Table 1. Eight Purposes that Public Managers Have for Measuring Performance

\begin{tabular}{|l|l|}
\hline The purpose & $\begin{array}{l}\text { The public manager's question that the performance measure can help } \\
\text { answer }\end{array}$ \\
\hline Evaluate & How well is my public agency performing? \\
\hline Control & How can I ensure that my subordinates are doing the right thing? \\
\hline Budget & $\begin{array}{l}\text { On what programs, people, or projects should my agency spend the public's } \\
\text { money? }\end{array}$ \\
\hline Motivate & $\begin{array}{l}\text { How can I motivate line staff, middle managers, non-profit and for-profit } \\
\text { collaborators, stakeholders, and citizens to do the things necessary to } \\
\text { improve performance? }\end{array}$ \\
\hline Promote & $\begin{array}{l}\text { How can I convince political superiors, legislators, stakeholders, journalists, } \\
\text { and citizens that my agency is doing a good job? }\end{array}$ \\
\hline Celebrate & $\begin{array}{l}\text { What accomplishments are worthy of the important organizational ritual of } \\
\text { celebrating success? }\end{array}$ \\
\hline Learn & Why is what working or not working? \\
\hline Improve & What exactly should who do differently to improve performance? \\
\hline
\end{tabular}

Source: Behn (2003) 
Thus, consistent with The Organisation for Economic Co-operation and Development (OECD), measuring government performance has long been recognised as necessary for improving the effectiveness and efficiency of the public sector.

\subsubsection{The Budget as a Performance Indicator}

The main financial document that reflects the state policy regarding the set up and the use of public resources is the budget (Attila, 2010). A budget is also a forecast of expenditures and revenue for a specific period of time; usually one year. As a planning document a budget enables business, government, private organizations and households to set the priorities and monitor progress toward selected goals (Abdullahi, 2011). To David (2007) the budget itself is a financial document, but in fact it is much more than that. It is a financial document that reflects program planning and service priorities in financial terms and also, ideally, in terms of performance expectations. Budget can be used as a benchmark, as a control system, that allows managers to compare actual performance with estimated or desired performance (Silva \& Jayamaha, 2012). Following David (2007) a good set of performance measures is a vital tool for building accountability and support of planning/budgeting efforts. True accountability means more than just assuring the public that revenues are properly collected and reported and that expenditures are made in accordance with prescribed procedures. Accountability includes these important assurances but also entails assurances to the public that government resources are being spent wisely as well as legally and that services of good quality are being produced efficiently. Therefore because the budget is the financial interface between the internal environment and the exterior environment of the entity (Attila, 2010), its performance in terms of its transparent implementation and execution, can be employed in judging the performance of the public sector.

\subsubsection{Budget Performance}

Operationally, in the words of KCL (2012) budget performance is defined as a comparison between estimated revenues and expenditures and actual revenues and expenditures resulting into either a deficit (where aggregate expenditures of the government is greater or more than its total revenues collected within a given period), a surplus (where government expenditures is less than its revenues) or an equilibrium/balanced budget (where total revenues of the government equal the total expenditures). A confirmation from Sheriffdeen (2012) indicate that while a surplus budget occurs when the proposed expenditure is less than the expected revenue, implying some saving at the end of the budget year, deficit budget is a situation in which the expected revenue is lower than the proposed expenditure, to be financed from accumulated savings or borrowings. Better still, balanced budget means equality between estimated revenue and proposed expenditure. The approach of defining budget performance in terms of deficit, surplus and balanced budget was adopted by Sahaj (2001) and the National Bank of Slovakia in measuring public sector budgetary performance results of the Slovak Republic for the year 2001 with efforts geared toward ensuring the steady progress of the state in implementing various reform measures of the government directed at gradually lowering or eliminating over the long term the deficit in the public sector budgetary performance. Graphically, these situations are depicted below: 
Graphical Presentation of Deficit, Surplus and Balanced Budget

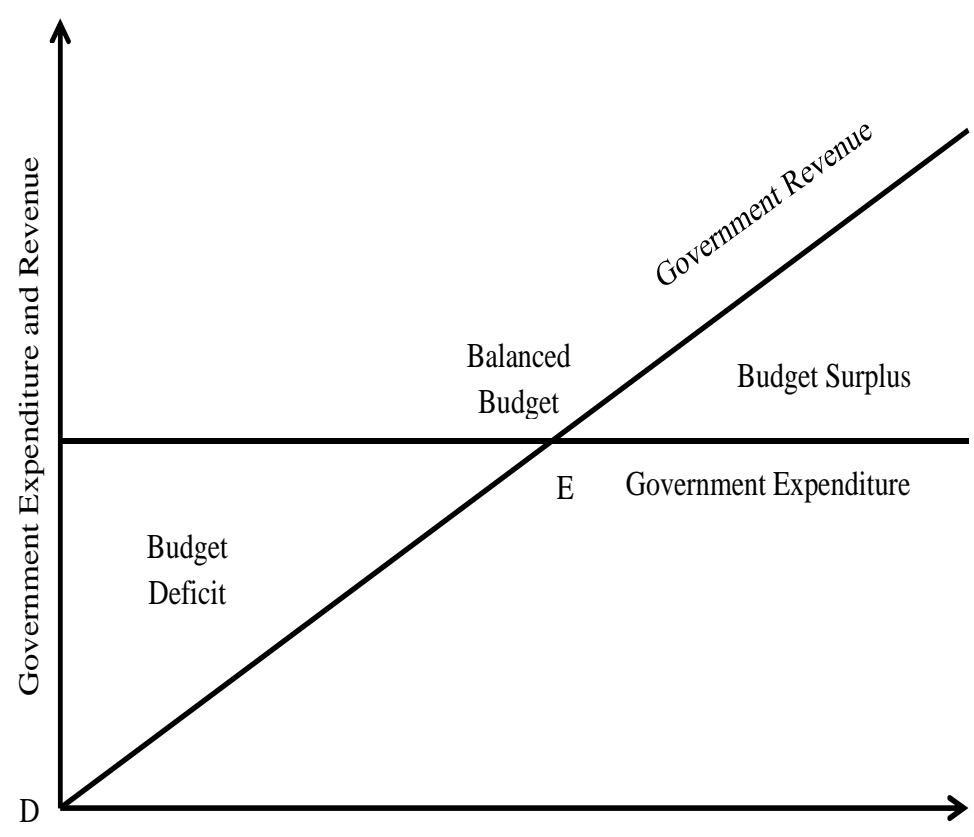

National Income

Source: Kalyan City Life Archive (2012)

At the Point $\mathrm{E}$, budget is balanced. To the left of point $\mathrm{E}$ the government budget is in deficit and to the right of point $\mathrm{E}$, the budget is in surplus.

Anwar \& Chunli (2007) giving reasons for the above levels of performance affirmed that when revenues are over estimated and expenditures underestimated, sharp expenditure cuts must be made later when executing the budget. On the revenue side, overestimation can come not only from technical factors, such as bad appraisal of the impact of a change in tax policy or of increased tax expenditures, but often also from the desire of politicians or ministries to keep in the budget an excessive number of programs while downplaying the difficulties of financing them. Similarly, on the expenditure side while underestimation can come from unrealistic assessments of the cost of unfunded liabilities (for example, benefits granted outside the budget) or of permanent obligations, underestimation can also be a deliberate tactic to launch new programs, with the intention of requesting increased appropriation later, during budget execution.

Unfortunately, governments are commonly reluctant to abandon an expenditure program after it has been started, forgetting that one should never throw good money after bad. When combined with bureaucratic and political momentum as well as vested interests, this natural reluctance leads to continuing an expenditure program even when a broad consensus exist that it is ineffective and wasteful. No technical improvement can by itself resolve institutional and 
political problems of this nature. It is that much more important, therefore, to put in place robust gate keeping mechanisms to prevent bad projects and programs from getting started in the first place. By the time they are in the budget pipeline, it is usually too late to stop them. An overoptimistic budget also leads to accumulation of government payment arrears, which create their own inefficiencies and destroy government credibility. Budget performance evaluation permits a smooth implementation of priority programs and prevents disruption of program management during budget execution. Political interference, corruption, administrative weakness and lack of needed information often lead to unrealistic budget which can never be executed well. Therefore, clear signals on the amount of expenditure compatible with financial constraints should be given to spending agencies at the start of the budget preparation process.

\subsubsection{Usefulness of Public Sector Performance Evaluation Results}

Consistent with Mackay (1998) developing national measurement capacities is a means for ensuring that measurement findings are available to assist countries in three areas. First, measurement findings can be an important input for government decision making and prioritization, particularly in the budget process. Second, measurement assists managers by revealing the performance of on-going activities at the project, program or sector levels-it is therefore a management tool which leads to learning and improvement in the future (i.e., results-based management). Similarly, measurement results can also be used to assess the performance of organizations and institutional reform processes. Third, measurement data contribute to accountability mechanisms, whereby managers and governments can be held accountable for the performance of their activities.

Public sector performance measurement results are equally inputs of public sector communications function which enables the effective flow of information and ideas within internal and external publics to facilitate participation, service delivery and informed decision-making and to build accountability and trust in government (New Zealand Government, 2010).

David (2007) also affirmed that good sets of performance measures have multiple uses including accountability/communication, support of planning/budgeting efforts, catalyst for improved operations, program evaluation, reallocation of resources, directing operations, contract monitoring and benchmarking.

\subsection{National Debt and Budget Performance}

National debt will arise where the actual expenditure exceeds actual revenue and it becomes necessary to source for means of financing the excessive expenditure. To meet the budgetary objections it is imperative to draw from savings set aside or to borrow from outside sources (Ndan 2009). Dalton in KCL (2012) confirming this, asserts that "If over a period of time expenditure exceeds revenue, the budget is said to be unbalanced". Deficit budget is one where the estimated government expenditure is more than expected revenue. Government estimated revenue is less than government's proposed expenditure. Such deficit amount is generally covered through public borrowings or withdrawing resources from the accumulated reserve surplus. 
Thus, a deficit budget is a liability to the government as it creates a burden of debt or it reduces the stock of reserves of the government. Budget deficit and its attendant debt burden are giant evils that most government fights against. While to Sahaj (2001) and the National Bank of Slovakia, "reform of the management of public finances is concerned with ensuring the steady progress of the state in implementing various reform measures of the government directed at gradually lowering or eliminating over the long term the deficit in the public sector budgetary performance”, Damian (2011) affirmed that if the interest payments on the national debt are not made, the US would be in default, potentially causing catastrophic economic consequences for the US and the wider world as well. Today's sovereign debt crisis highlights some of the consequences of poor financial management and weak financial reporting in the public sector (Ball, 2009).

Judging from the United States perspective, the federal government can pay for expenditures only if Congress has approved the expenditure. If the total expenditure exceeds the revenues collected there is a budget deficit, and the only way that the shortfall can be paid for is for the government, through the Department of the Treasury, to borrow the shortfall amount by the issue of debt instruments. Under federal law, the amount that the government can borrow is limited by the debt ceiling, which can only be increased with a vote by Congress. In compliance with the provisions of the federal law, the Treasury lamented that "failing to increase the debt limit would ... cause the government to default on its legal obligations - an unprecedented event in American history". These legal obligations include paying Social Security and Medicare benefits, military salaries, interest on the debt, and many other items. These legal and formal procedures are normally faulted in developing countries like Nigeria thereby leaving the country with high level of debt burden.

Anwar \& Chunli (2007) equally posits that the summary indicator of a country's fiscal position used commonly is the overall balance on a cash basis, defined as the difference between actual collected revenues plus grants (cash or in kind) and actual expenditure payments. The cash deficit is by definition equal to the government borrowing requirements (from domestic or foreign sources) and is thus integrally linked to the money supply and inflation targets and prospects. The overall deficit is obviously a major policy target and is used for international comparisons as well. How the deficit is financed (debt implication) also requires attention: the same level of fiscal deficit can be manageable or not, depending on whether it is financed in cost-effective and non-inflationary ways.

\subsection{Constraints of Performance Measurement of Public Sector}

Some features of the public sector serve to make effective performance measurement harder in the public sector. CIMA identified the following features of the public sector as responsible in complicating performance measurement of the public sector.

- The lack of a predominant profit motive to simplify resource allocation. Private sector organisations can relatively easily determine where to invest effort and resource to maximise overall results. Although many public sector organisations have revenue generating or even profit making elements, their predominant objective is to deliver services to achieve certain 
outcomes. Those services must be delivered to users who may not wish to receive them, or who may not value them.

- Politics, which affect almost everything from the very nature of the public sector to governance arrangements and the frequency and philosophy behind reform efforts.

- Complicated delivery chains and multiple stakeholders which make it more difficult to manage activities. Public sector bodies often use other bodies or stakeholders to help them deliver services. For example, funding for a service might be decided at national level and then devolved to local bodies, which might use third sector organisations to deliver services.

- Unclear cause and effect relationships - public sector objectives such as increasing literacy, or reducing street crime, are affected by many different issues cutting across different programmes and organisations. The effect of changing any single factor cannot be easily isolated.

- Delayed impacts - achievement or progress towards many public sector objectives, particularly those which are preventative, may not be observable for many years or even decades.

- Attitudes towards accountability and transparency. Many countries struggle with corruption, nepotism, poor governance or a lack of openness. Even policy makers in countries without these problems may resist scrutiny of popular or politically motivated, rather than evidence-based decisions.

Equally according to IPAC the barriers to effective performance measurement fall into several categories, which include: methodological barriers, financial barriers, government barriers and political and public service barriers.

\subsection{Nigeria Country Profile}

Nigeria, the study area covers an area of 923,768sq km (356,669sq mile). It is bounded by Cameroon to the east, Chad to the northeast, Niger to the north, Benin to the west, and Gulf of Guinea on the Atlantic Ocean to the south (Ofem, 2012). Going by the most recent national census held in 2006, Nigeria has a population of over 140 million inhabitants out of which about $48 \%$ live in urban centres. It is the most populated country in Africa and accounts for more than 25 percent of the population of sub-Saharan Africa. Nigeria is administratively divided into 36 states and the Federal Capital Territory. Nigeria practice democracy in federalism. The states are further divided into 774 local government areas. Between it and the republic of South Africa they account for more than 50 percent of sub-Saharan Africa GDP. Nigeria as a member of Organization of Petroleum Exporting countries produces an average of 2.3 million barrels of oil per day and it is reckoned to be the sixth largest oil producer in the world. 
Table 2. Nigeria key macroeconomic indications (growth rates): The variance level

\begin{tabular}{|l|l|l|l|l|l|}
\hline Variable/year & 2006 & 2007 & 2008 & 2009 & 2010 \\
\hline Inflation & & & & & \\
\hline Actual & 8.55 & 6.56 & 15.06 & 13.93 & 11.80 \\
\hline Target & 9.00 & 9.00 & 9.00 & 9.00 & 11.20 \\
\hline Variance & 0.45 & 2.44 & -6.06 & -4.93 & -0.6 \\
\hline Real GDP & & & & & \\
\hline Actual & 6.03 & 6.45 & 5.98 & 6.96 & 7.87 \\
\hline Target & 7.00 & 10.00 & 7.50 & 5.00 & 6.10 \\
\hline Variance & -0.97 & -3.55 & -1.52 & 1.96 & 1.77 \\
\hline $\mathrm{M}_{1}$ & & & & & \\
\hline Actual & 32.18 & 37.63 & 56.07 & 2.41 & 11.05 \\
\hline Target & - & - & - & 32.20 & 22.40 \\
\hline Variance & - & - & - & -29.79 & -11.35 \\
\hline
\end{tabular}

Source: Sheriffdeen (2012)

\section{Methodology}

The objective of this study is to investigate the relationship between budget performance and national debt as measures of public sector performance. The period of study spans from 1960 2010. The data collected are subjected to regression analysis labeling budget performance as the independent variable and national debt (including domestic and external debt) as the dependent variables. The Augmented Dickey-Fuller Tests equation was employed to perform unit root tests for stationary and cointegration tests. A comparative descriptive analysis of cross country ratio of debt to GDP is equally provided.

\section{Data Presentation, Analysis and Interpretation}

In analyzing the data three equations were formulated having budget performance as the independent variables in the three equations and domestic debt, external debt and total national debt as the dependent variables in these equations. Thus these three equations are named domestic debt (DD), external debt (EX) and total debt (TD) models.

\subsection{Regression Analysis for Domestic Debt}

The Regression equation is

Domestic Debt $=177280.9-4.0715$ Surp/Deficit

Dependent Variable: DD

Method: Least Squares

Date: 07/19/13 Time: 16:45

Sample: 19612010

Included observations: 50 


\begin{tabular}{lrlrr}
\hline \multicolumn{1}{c}{ Variable } & Coefficient & \multicolumn{1}{c}{ Std. Error } & t-Statistic & Prob. \\
\hline \multicolumn{1}{c}{ C } & 177280.9 & 70778.52 & 2.504727 & 0.0157 \\
\multicolumn{1}{c}{ BP } & -4.071474 & 0.332018 & -12.26282 & 0.0000 \\
\hline \hline R-squared & 0.758036 & Mean dependent var & 508840.8 \\
Adjusted R-squared & 0.752995 & S.D. dependent var & 930638.3 \\
S.E. of regression & 462523.3 & Akaike info criterion & 28.96596 \\
Sum squared resid & $1.03 E+13$ & Schwarz criterion & 29.04244 \\
Log likelihood & -722.1490 & Hannan-Quinn criter. & 28.99508 \\
F-statistic & 150.3767 & Durbin-Watson stat & 0.706773 \\
Prob(F-statistic) & 0.000000 & & \\
\hline \hline
\end{tabular}

The estimated coefficient $b_{1}$, the intercept in our domestic debt model is recorded as the coefficient on the variable $\mathrm{C}$ in this study. $\mathrm{C}$ is the term for constant in a regression model. Results show $b_{1}=177280.9$. The estimated value of the slope coefficient on the variable annual budget performance $(X)$ is $b_{2}=-4.0715$. The interpretation of $b_{2}$ is: for every N4.0715 budget deficit this study estimates that there is about a N100 increase in domestic debt, holding all other factors.

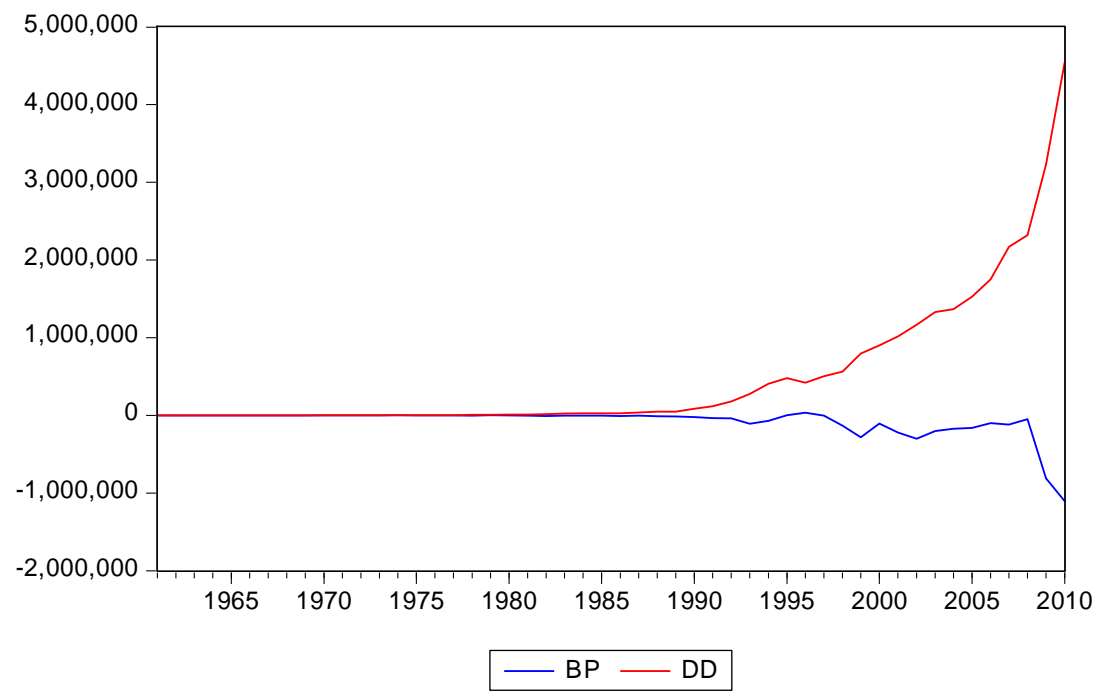

Figure 1. Domestic Debt Model Graph

\subsection{Regression Analysis for External Debt}

The Regression equation is

External Debt $=493244.5-2.0719$ Surp/Deficit 


\section{Macrothink}

Dependent Variable: ED

Method: Least Squares

Date: 07/19/13 Time: 16:46

Sample: 19612010

Included observations: 50

\begin{tabular}{lllll}
\hline \hline Variable & Coefficient & Std. Error & t-Statistic & Prob. \\
\hline \hline C & 493244.5 & 181195.1 & 2.722174 & 0.0090 \\
BP & -2.071900 & 0.849975 & -2.437599 & 0.0185 \\
\hline \hline R-squared & 0.110154 & Mean dependent var & 661969.3 \\
Adjusted R-squared & 0.091615 & S.D. dependent var & 1242349. \\
S.E. of regression & 1184073. & Akaike info criterion & 30.84600 \\
Sum squared resid & $6.73 E+13$ & Schwarz criterion & 30.92248 \\
Log likelihood & -769.1499 & Hannan-Quinn criter. & 30.87512 \\
F-statistic & 5.941891 & Durbin-Watson stat & 0.245478 \\
Prob(F-statistic) & 0.018540 & & \\
\hline \hline
\end{tabular}

Equally, results show $b_{1}=493244.5$. The estimated value of the slope coefficient on the variable annual budget performance $(X)$ is $b_{2}=-2.0719$. The interpretation of $b_{2}$ is: each time government expenditure exceeds revenues by N2.0719 (budget deficit of N-2.0719) this study estimates that there is a consequential effect of about N100 increase in external debt, holding all other factors.

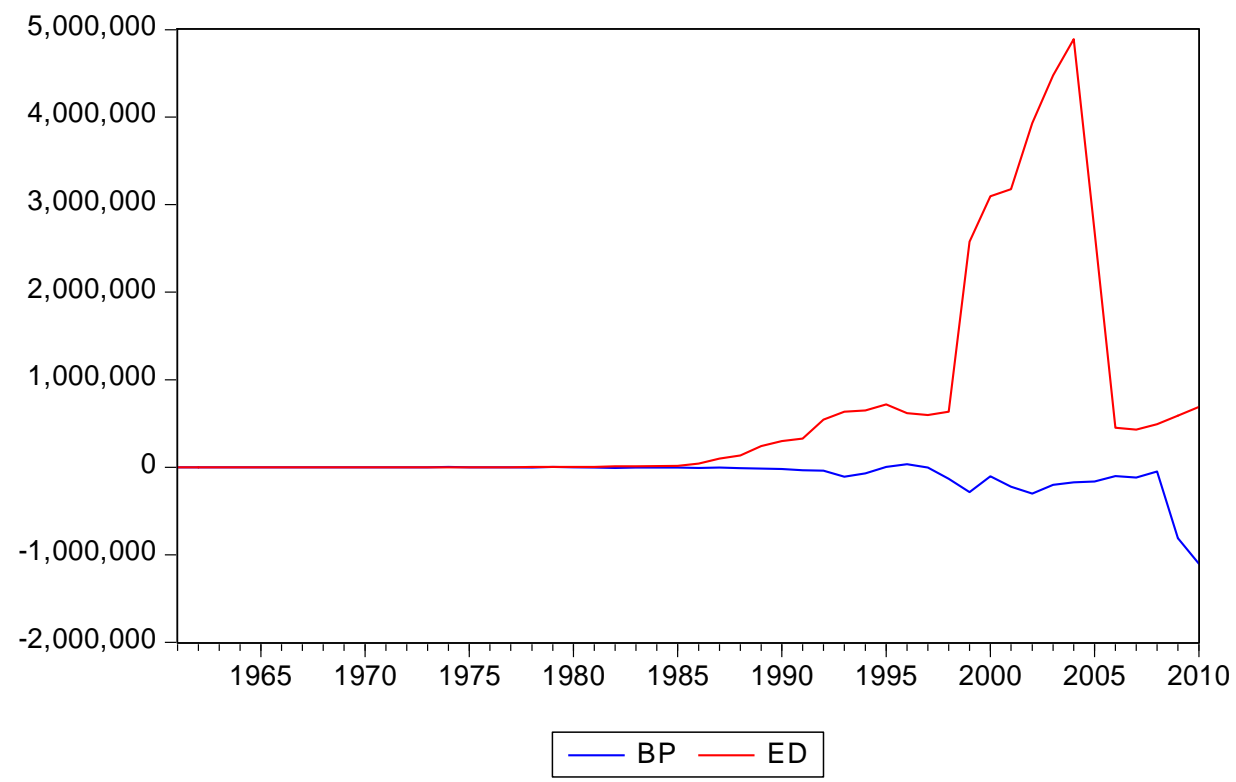

Figure 2. External Debt Model Graph 


\section{Macrothink}

\subsection{Regression Analysis for Total National Debt}

The Regression equation is

Total National Debt $=669311-6.145$ Surp/Deficit

Dependent Variable: TD

Method: Least Squares

Date: 07/19/13 Time: 16:46

Sample: 19612010

Included observations: 50

\begin{tabular}{lllll}
\hline \hline Variable & \multicolumn{2}{l}{ Coefficient Std. Error } & t-Statistic & Prob. \\
\hline \hline C & 669311.0 & 209085.5 & 3.201136 & 0.0024 \\
BP & -6.145025 & 0.980808 & -6.265270 & 0.0000 \\
\hline \hline R-squared & 0.449880 & Mean dependent var & 1169730. \\
Adjusted R-squared & 0.438419 & S.D. dependent var & 1823264. \\
S.E. of regression & 1366331. & Akaike info criterion & 31.13233 \\
Sum squared resid & $8.96 E+13$ & Schwarz criterion & 31.20882 \\
Log likelihood & -776.3084 & Hannan-Quinn criter. & 31.16146 \\
F-statistic & 39.25361 & Durbin-Watson stat & 0.324590 \\
Prob(F-statistic) & 0.000000 & & \\
\hline \hline
\end{tabular}

Finally, analysis show $b_{1}=669311$. The estimated value of the slope coefficient on the variable annual budget performance $(X)$ is $b_{2}=-6.145$. The interpretation of $b_{2}$ is: for every budget deficit of N-6.145 this study estimates that there is every likely hood that total debt will increase to about N100, all things being equal.

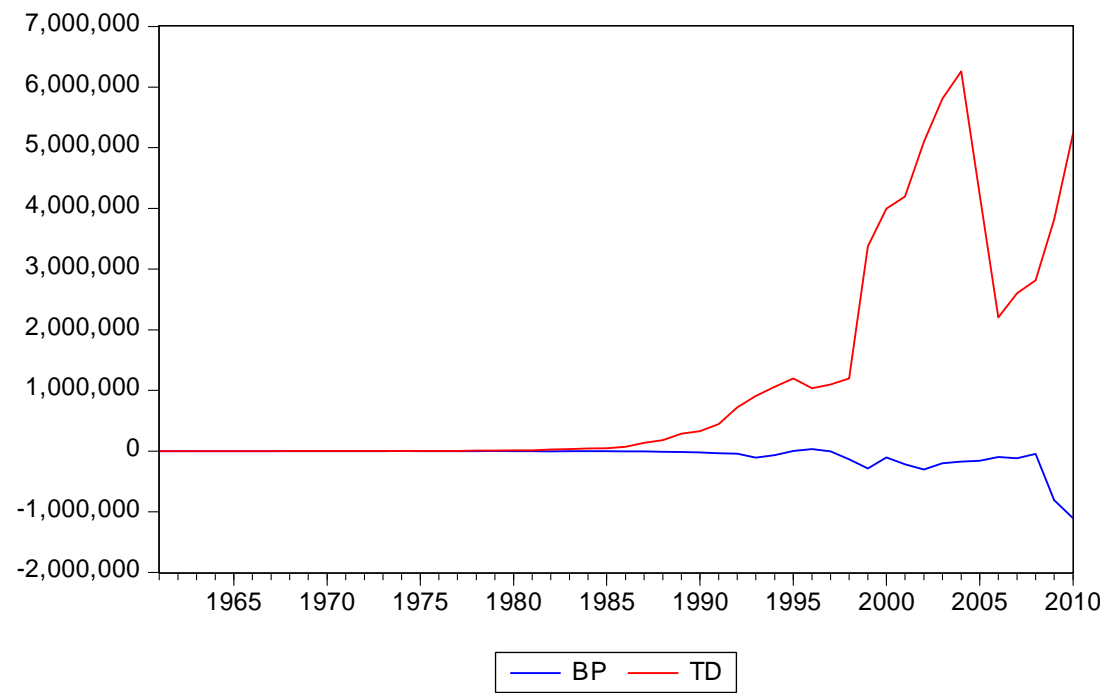

Figure 3. Total Debt Model Graph 
In summary, results show that much easier and quicker for budget deficit to give rise to external debt than domestic and total debt. While a deficit of N2 will give rise to external debt of N100, budget deficit must get hit N4 and N6 in order to generate respectively domestic and total debt of N100. In all, the costs of adverse budget performance outweigh its benefits. N2 to N6 budget deficit resulting to debt of N100 is by all judgement not rational, outrageous and extremely costly. Therefore it is recommended that government operates within the provisions of the budget to avoid budget deficit and its attendant costs.

\subsection{Descriptive Statistics}

\begin{tabular}{lcccc}
\hline & BP & DD & ED & TD \\
Mean & -81434.85 & 508840.8 & 661969.3 & 1169730. \\
Median & -3633.300 & 28193.90 & 29376.50 & 57570.40 \\
Maximum & 32049.40 & 4551822. & 4890270. & 6260595. \\
Minimum & -1105440. & 53.30000 & 49.80000 & 103.1000 \\
Std. Dev. & 199009.6 & 930638.3 & 1242349. & 1823264. \\
Skewness & -3.840032 & 2.496145 & 2.193500 & 1.468938 \\
Kurtosis & 18.42139 & 9.629519 & 6.618014 & 3.802311 \\
& & & & \\
Jarque-Bera & 618.3390 & 143.4864 & 67.36623 & 19.32253 \\
Probability & 0.000000 & 0.000000 & 0.000000 & 0.000064 \\
Sum & & & & \\
Sum Sq. Dev. & $1.94 \mathrm{E}+12$ & $4.24 \mathrm{E}+13$ & $7.56 \mathrm{E}+13$ & $1.63 \mathrm{E}+14$ \\
Observations & 50 & & & 50 \\
\hline
\end{tabular}

The surface observation of data collected for this study evidenced that the nation's debt keep increasing as the nation's actual expenditure outweighs revenue (deficit) though not proportionately suggesting that there is a significant negative relationship between budget performance in the form of surplus, deficit or balance budget and domestic, external and national debt. The above present the descriptive statistics for all the variables including budget performance (BP), domestic (DD), eternal (ED) and total (TD) debt. The descriptive statistics for all the dependent variables mean median, maximum and minimum exhibit positive results. On the other hand the mean and median for budget performance is negative implying that the performance of the Nigeria budget has consistently being in deficit particularly since 1981 till date resulting into geometric increase in total national debt and its attendant burden and that a negative relationship exist between budget performance and domestic, external and total debt.

\subsection{Cross Country Debt to GDP as Economic Progress Indicator (\%)}

For more than a half century, the most widely accepted measure of a country's economic progress has been changes in its Gross Domestic Product (GDP). The GDP has maintained a firm position as a dominant economic indicator. Indeed, most economists in business and government, teachers of economics at various levels of education, and journalists, policy 
makers and politicians (regardless of their political preferences) continue to give much importance to GDP and calling for unconditional GDP growth (Jeroen, 2009).

GDP is an estimate of market throughput, adding together the value of all final goods and services that are produced and traded for money within a given period of time. It is typically measured by adding together a nation's personal consumption expenditures (payments by households for goods and services), government expenditures (public spending on the provision of goods and services, infrastructure, debt payments, etc.), net exports (the value of a country's exports minus the value of imports), and net capital formation (the increase in value of a nation's total stock of monetized capital goods) (Costanza, Hart, Posner \& Talberth, 2009). In summary, Jeroen (2009) affirmed that gross domestic product (GDP) is the monetary, market value of all final goods and services produced in a country over a period of a year.

Due to the fact that GDP is a fundamental universal economic indicator and the real GDP per capita (corrected for inflation) is generally used as the core indicator in judging the position of the economy of a country over time or relative to that of other countries (Jeroen, 2009), this study establishes a relationship in the form of the ratio between total debt and GDP for some countries. This ratio measures the portion of a nation's GDP attributable to debt or how much of a nation's GDP that can provide coverage for her total debt. The result of the analysis of data for period 2000 - 2010 is presented below:

\begin{tabular}{lcccccc}
\hline & AUSTRALIA & AUSTRIA & BELGIUM & CANADA & CHILE & CZECH_REP_ \\
\hline Mean & 7.745455 & 61.42727 & 93.74545 & 33.67273 & 9.563636 & 23.06364 \\
Median & 7.500000 & 60.90000 & 94.90000 & 35.70000 & 9.200000 & 23.20000 \\
Maximum & 11.40000 & 65.80000 & 99.50000 & 40.90000 & 15.70000 & 36.60000 \\
Minimum & 4.900000 & 57.80000 & 85.30000 & 25.20000 & 4.100000 & 13.20000 \\
Std. Dev. & 2.234441 & 2.299605 & 4.685160 & 5.181716 & 4.232794 & 7.292636 \\
Skewness & 0.369526 & 0.570895 & -0.449502 & -0.195987 & 0.162414 & 0.392131 \\
Kurtosis & 1.899267 & 2.784052 & 2.058818 & 1.767808 & 1.498793 & 2.285764 \\
& & & & & & \\
Jarque-Bera & 0.805663 & 0.618895 & 0.776431 & 0.766306 & 1.081270 & 0.515717 \\
Probability & 0.668425 & 0.733852 & 0.678266 & 0.681708 & 0.582378 & 0.772705 \\
& & & & & & \\
Sum & 85.20000 & 675.7000 & 1031.200 & 370.4000 & 105.2000 & 253.7000 \\
Sum Sq. Dev. & 49.92727 & 52.88182 & 219.5073 & 268.5018 & 179.1655 & 531.8255 \\
Observations & 11 & & & & & \\
\hline
\end{tabular}




\begin{tabular}{|c|c|c|c|c|c|c|}
\hline & DENMARK & ESTONIA & FINLAND & FRANCE & GERMANY & GREECE \\
\hline Mean & 42.23636 & 2.663636 & 39.34545 & 53.60000 & 40.02727 & 113.8727 \\
\hline Median & 39.60000 & 2.900000 & 41.30000 & 52.10000 & 39.60000 & 109.7000 \\
\hline Maximum & 54.80000 & 3.600000 & 48.00000 & 67.40000 & 44.40000 & 147.8000 \\
\hline Minimum & 27.80000 & 1.300000 & 29.50000 & 47.40000 & 36.50000 & 105.7000 \\
\hline Std. Dev. & 9.220767 & 0.797838 & 5.618071 & 5.804653 & 2.535780 & 12.64002 \\
\hline Skewness & -0.098987 & -0.382685 & -0.395605 & 1.403094 & 0.539173 & 2.054162 \\
\hline Kurtosis & 1.629325 & 1.763231 & 2.280921 & 4.076940 & 2.400279 & 5.889990 \\
\hline Jarque-Bera & 0.879058 & 0.969553 & 0.523916 & 4.140811 & 0.697811 & 11.56392 \\
\hline Probability & 0.644340 & 0.615835 & 0.769543 & 0.126135 & 0.705460 & 0.003083 \\
\hline Sum & 464.6000 & 29.30000 & 432.8000 & 589.6000 & 440.3000 & 1252.600 \\
\hline Sum Sq. Dev. & 850.2255 & 6.365455 & 315.6273 & 336.9400 & 64.30182 & 1597.702 \\
\hline Observations & 11 & 11 & 11 & 11 & 11 & 11 \\
\hline
\end{tabular}

\begin{tabular}{|c|c|c|c|c|c|c|}
\hline & HUNGARY & ICELAND & IRELAND & ISREAL & ITALY & KOREA \\
\hline Mean & 60.54545 & 40.92727 & 31.38182 & 85.39091 & 100.3182 & 25.18182 \\
\hline Median & 58.10000 & 33.80000 & 27.90000 & 83.40000 & 98.10000 & 27.60000 \\
\hline Maximum & 73.90000 & 87.50000 & 60.70000 & 97.80000 & 109.0000 & 32.60000 \\
\hline Minimum & 50.40000 & 19.40000 & 19.80000 & 74.70000 & 95.60000 & 16.70000 \\
\hline Std. Dev. & 7.908143 & 22.70036 & 12.32167 & 8.973233 & 4.535597 & 6.143748 \\
\hline Skewness & 0.576880 & 1.291691 & 1.419763 & 0.148276 & 0.794156 & -0.279550 \\
\hline Kurtosis & 2.045054 & 3.221162 & 4.003810 & 1.464425 & 2.250193 & 1.456844 \\
\hline Jarque-Bera & 1.028081 & 3.081271 & 4.157334 & 1.121052 & 1.413934 & 1.234716 \\
\hline Probability & 0.598074 & 0.214245 & 0.125097 & 0.570909 & 0.493138 & 0.539368 \\
\hline Sum & 666.0000 & 450.2000 & 345.2000 & 939.3000 & 1103.500 & 277.0000 \\
\hline Sum Sq. Dev. & 625.3873 & 5153.062 & 1518.236 & 805.1891 & 205.7164 & 377.4564 \\
\hline Observations & 11 & 11 & 11 & 11 & 11 & 11 \\
\hline
\end{tabular}

\begin{tabular}{lcccccc}
\hline & LUXEMBOUR & MEXICO & \multicolumn{2}{c}{ NETHERLAND } & NEWZEALAND NIGERIA & NORWAY \\
\hline Mean & 4.100000 & 22.56364 & 44.10000 & 25.76364 & 42.85455 & 18.53636 \\
Median & 2.700000 & 21.20000 & 43.00000 & 26.40000 & 29.00000 & 18.40000 \\
Maximum & 12.60000 & 28.10000 & 51.80000 & 32.10000 & 88.70000 & 26.40000 \\
Minimum & 0.800000 & 20.30000 & 37.60000 & 20.30000 & 11.60000 & 11.70000 \\
Std. Dev. & 3.875306 & 2.835233 & 4.582794 & 4.269256 & 32.00376 & 4.838858 \\
\hline
\end{tabular}




\begin{tabular}{|c|c|c|c|c|c|c|}
\hline Skewness & 1.184075 & 1.169848 & 0.450761 & 0.057874 & 0.335441 & 0.276811 \\
\hline Kurtosis & 3.017364 & 2.770231 & 2.061520 & 1.514452 & 1.399990 & 2.233659 \\
\hline Jarque-Bera & 2.570534 & 2.533194 & 0.776182 & 1.017615 & 1.379636 & 0.409647 \\
\hline Probability & 0.276577 & 0.281789 & 0.678351 & 0.601212 & 0.501667 & 0.814791 \\
\hline Sum & 45.10000 & 248.2000 & 485.1000 & 283.4000 & 471.4000 & 203.9000 \\
\hline Sum Sq. Dev. & 150.1800 & 80.38545 & 210.0200 & 182.2655 & 10242.41 & 234.1455 \\
\hline Observations & 11 & 11 & 11 & 11 & 11 & 11 \\
\hline
\end{tabular}

\begin{tabular}{lcccccc}
\hline & POLAND & PORTUGAL & \multicolumn{2}{c}{ SLOVAK_REP_SPAIN } & SWEEDEN & SWITZERLAND \\
\hline Mean & 43.20000 & 65.29091 & 32.53636 & 40.99091 & 43.53636 & 24.98182 \\
Median & 44.70000 & 66.20000 & 33.70000 & 40.70000 & 46.20000 & 25.20000 \\
Maximum & 49.70000 & 88.00000 & 39.10000 & 51.70000 & 56.90000 & 28.30000 \\
Minimum & 35.80000 & 52.10000 & 23.90000 & 30.00000 & 33.80000 & 20.20000 \\
Std. Dev. & 4.198571 & 10.76777 & 4.980617 & 7.194644 & 6.991033 & 3.038361 \\
Skewness & -0.550736 & 0.789402 & -0.383416 & -0.025881 & 0.221513 & -0.299018 \\
Kurtosis & 2.551968 & 2.889988 & 1.939694 & 1.761064 & 2.280705 & 1.718225 \\
& & & & & & \\
Jarque-Bera & 0.648072 & 1.147999 & 0.784795 & 0.704753 & 0.327093 & 0.916939 \\
Probability & 0.723224 & 0.563268 & 0.675435 & 0.703016 & 0.849127 & 0.632251 \\
& & & & & & \\
Sum & 475.2000 & 718.2000 & 357.9000 & 450.9000 & 478.9000 & 274.8000 \\
Sum Sq. Dev. & 176.2800 & 1159.449 & 248.0655 & 517.6291 & 488.7455 & 92.31636 \\
Observations & 11 & 11 & & & & \\
\hline
\end{tabular}

\begin{tabular}{llll}
\hline & TURKEY & U_K & USA \\
\hline Mean & 51.43636 & 50.00909 & 39.39091 \\
Median & 46.40000 & 42.70000 & 36.00000 \\
Maximum & 74.10000 & 85.50000 & 61.30000 \\
Minimum & 38.20000 & 38.70000 & 32.40000 \\
Std. Dev. & 12.45546 & 16.42592 & 9.314124 \\
Skewness & 0.662118 & 1.316526 & 1.607802 \\
Kurtosis & 2.066522 & 3.139504 & 4.047307 \\
& & & \\
Jarque-Bera & 1.203116 & 3.186530 & 5.241943 \\
Probability & 0.547957 & 0.203261 & \\
& & & 433.3000
\end{tabular}


These data can equally be employed to assess government risk which entails identifying and evaluating events (i.e., possible risks and opportunities) that could affect the achievement of government overall socio-economic objectives, positively or negatively. When a government carries high debt burden for example Greece, such situation is highly likely to intersect with a government's objectives - or can be predicted to do so-it become a risk. The above assertion is consistent with PricewaterhouseCoopers (2008) that risk as "the possibility that an event will occur and adversely affect the achievement of objectives. Therefore following PricewaterhouseCoopers (2008) risk map this study classified these countries into low, medium and highly debt burdened countries.

Countries with mean of debt to GDP ratio of less than $10 \%$ are classified as low debt burdened countries, $10-50 \%$ medium debt burdened countries and greater than 50\% high debt burdened countries. By this classification, Australia, Chile, Estonia and Luxembourg are low debt burdened countries. Canada, Czech Republic, Denmark, Finland, Germany, Iceland, Ireland, Korea, Mexico, Netherlands, New Zealand, Nigeria, Norway, Poland, Slovak Republic, Spain, Sweden, Switzerland and USA are within the category of medium debt burdened countries. Finally, Austria, Belgium, France, Greece, Hungary, Israel, Italy, Portugal, Turkey and U.K are highly debt burdened. Estonia has the lowest mean of debt to GDP ratio of $2.66 \%$ and Greece exhibit the highest ratio of $113.87 \%$. This is indicative that averagely, the GDP of Greece is not adequate to provide coverage for her debt burden. The negative but catastrophic burden of debt is evidenced by the current economic crisis Greece as the highest debt burdened country is experiencing.

Though Nigeria by this classification falls within the class of medium debt burdened nation with a mean of debt to GDP of $42.85 \%$ and median of $29 \%$ there is every need to be courteous and on the watch out as her path of budget performance in terms of deficit that leads to the three forms of debt burden from the above analysis is quite slippery. 

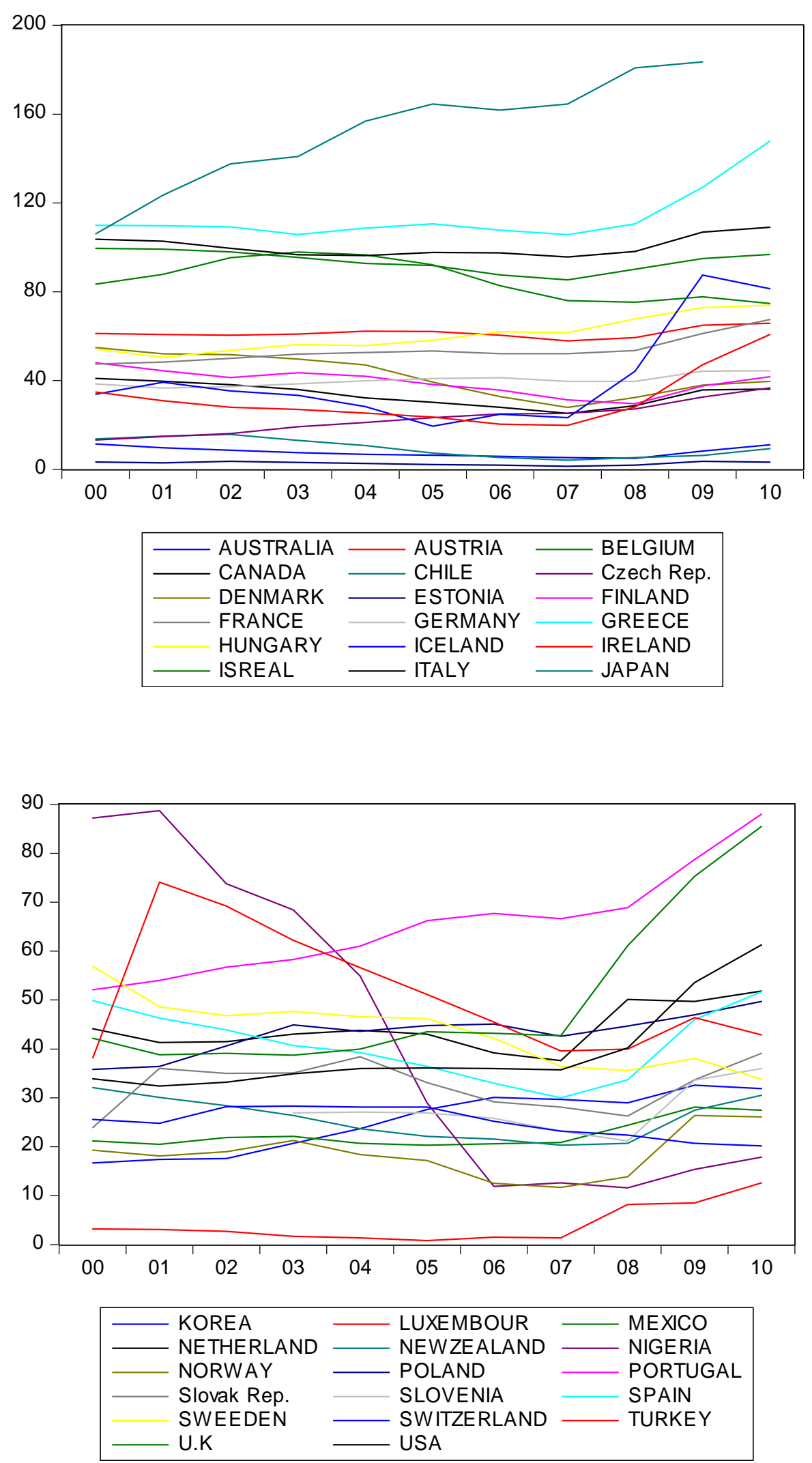

Figure 4 and 5. Cross-Country Debt to GDP(\%) Graph 


\subsection{Unit Root Tests for Stationary}

This study test whether the time series is stationary or nonstationary in order to avoid the danger of obtaining apparently significant regression results from unrelated data when nonstationary series are used in regression analysis. Such regressions are said to be spurious. Thus this study perform unit root tests for stationary for all the variables (BP, DD, ED and TD) using the Augmented Dickey-Fuller Tests equation. Since calculated Dickey-Fuller tests statistics for budget performance (0.338072), domestic debt (3.672291), external debt $(-2.526719)$ and total debt $(-0.883949)$ are all greater than $5 \%$ critical value of $(-2.923780)$, this study did not reject the null of nonstationary. In other words, the variables budget performance (BP), domestic debt (DD), external debt (ED) and total debt (TD) are nonstationary series.

\subsection{Conintegration Tests}

To tests whether the nonstationary variables BP, DD, ED and TD are cointegrated, this study equally examined separately the properties of the three regression residuals (DD $=177280.9$ - 4.0715 BP, ED = 493244.5 - 2.0719 BP and TD = 669311 - 6.145 BP). Since calculated Dickey-Fuller tests statistics for DD = 177280.9 - 4.0715 BP (-2.938060), ED = $493244.5-$ 2.0719 BP (-2.327642) and TD = 669311 - 6.145 BP (-2.047329) are all less than 5\% critical value for regression-based cointegration tests of (3.37), this study reject the null of no integration. In other words, the variables in the three regressions are cointegrated.

\subsection{Model Explanatory Powers}

Goodness of fit (i.e., $\mathrm{r}^{2}$ ) provides an indication of the variation in the dependent variable being explained by the independent variable(s) in a regression model (Jordan, Waldron \& Clark, 2007). It is often used as a measure of the comparative predictive and explanatory abilities among models (e.g., see Dechow, Hutton, Kim \& Sloan, 2011; Jordan, Waldron \& Clark, 2007; Greenburg, Johnson \& Ramesh, 1986; Murdoch \& Krause, 1989; McBeth, 1993). Generally, the higher the $r^{2}$, the greater is the predictive and explanatory power of a model. Using $r^{2}$ as a gauge of explanatory power, the equation investigating the relationship between budget performance and domestic debt possesses superior explanatory ability with $r^{2}$ of $76 \%$ over both equations investigating the relationship between budget performance and external and total national debt respectively possessing $\mathrm{r}^{2} \mathrm{~s}$ of $11 \%$ and $45 \%$.

Following Jordan, Waldron \& Clark (2007), Lorek \& Willinger (1996), Cheung \& Krishnan (1997) and Neter \& Wasserman (1974) models with higher $r^{2}$ s may not necessarily be the best predictors. This is because even a model with a high $\mathrm{r}^{2}$ may have a mean square error that is too large for inferences to be drawn when accurate predictions are needed (Neter \& Wasserman, 1974, p. 229). Jordan, Waldron \& Clark (2007) and Akresh \& Wallace (1982) state that predictive ability is best examined not only by evaluating a model's $r$ but also by analyzing the size of the residuals or error terms resulting from the model's predictions. 


\subsection{Implications for Past and Appeal to Present Nigeria Administrations}

This paper discovers that between 1960 and 1980, the Nigerian government experience 13 years of surplus budget and 7 years of deficit budget. The frequency of budget deficit was lower compared to its corresponding surplus budget. From 1981 till 2010, except in 1995, Nigeria budget has been in deficit. This result is consistent with Sheriffdeen (2012) and Abdullahi \& Angus (2012) who respectively affirmed that preparation and presentation of the budget by the president of Nigeria has become more of a fanfare in recent time than a serious business it was up to the mid-1980s and that many a time government budgets in developing countries like Nigeria is nothing but addition of figures only to be read to the ears of the public and departure from budget items amount to disastrous development, conflicts, scandals and corruption of administration.

This study equally provide evidence of the failure of past and present Nigerian administrations' deliberate refusal to execute and implement government programs and activities within the ambit of the provisions of the budget. This position is equally cemented in the light of the assertion of Sheriffdeen (2012) that though virtually all countries around the world engage in deficit budgeting, the Nigerian case is a mystery and difficult to explain even by experts. This is because the Nigerian budget is prepared based on U.S \$ 75 per barrel of oil and $x$ number of barrel per day. At the end of the year, the variables turn out to be better than expectations, that is, the oil output remain greater than the estimates and the price of crude oil would average about $\$ 100$ per barrel with no corresponding growth in the country's reserves, yet we claim to have budget deficit.

To this end, our cry is Nigeria government “don’t let our future dry up”.

\section{Conclusions and Recommendations}

Consistent with IPAC, public sector performance measurement is imperative as it can bring substantial benefits to governments in the form of greater efficiency, effectiveness and accountability, but there are substantial obstacles to its successful implementation. Because the budget is a financial document that reflects program planning and service priorities in financial terms and also, ideally, in terms of performance expectations and can be used as a benchmark, as a control system, that allows managers to compare actual performance with estimated or desired performance, investigating the relationship between its performance and national debt is appropriate and adequate in measuring the performance of public sector. There exist a negative relationship between budget performance and debt burden. Meaning that the more the budget goes into deficit the more the debt burden of a nation and vice versa. National debt and its attendant costs are liabilities to the government which are capable of putting a nation in a state of perpetual economic slavery and hopelessness for the generation unborn.

From the above findings, the following recommendations are made. First, in agreement with Abdullahi \& Angus (2012), it is recommended that the budget document which is a plan of activities should be followed item after item in its implementation and execution. In addition, following Ball (2009) Nigeria government should as a matter of transparent accountability 
prepare budget on accrual basis and put in place structures and mechanisms that will ensure the enactment of federal law making provisions for the amount that the government can borrow and the debt ceiling, which can only be increased with a vote by National Assembly.

\section{References}

Abdullahi, A. M., \& Angus, O. U. (2012). Budget in Nigeria Public Sector: Need for Balanced Scorecard Perspective. International Journal of Finance and Accounting, 1(2), 1-6. http://dx.doi.org/10.5923/j.ijfa.20120102.01

Abdullahi, Y. S. (2011). Public Budget and Budgetary Control in Nigeria. Journal of Business and Organizational Development, 3, 21-27.

Akresh, A., \& Wallace, W. (1982). The Application of Regression Analysis for Limited Review and Audit Planning. Symposium on Audit Research IV, University of Illinois at Urbana - Champaign, 43-68.

Anwar S., \& Chunli S. (2007). Public Sector Governance and Accountability Series: Budgeting and Budgetary Institutions. Washington DC, IBRD/World Bank.

Attila, G. (2010). Public budgets: New challenges. Budgetary Research Review (BRR), ISSN 2067-1784. Buget Finante, 2(1), 1-25.

Ball, I. (2009). Public Sector Performance: A Global Perspective. Chief Executive Officer IFAC.

Behn, R. D. (2003). Why Measure Performance? Different Purposes Require Different Measures. Public Administration Review, 63 (September 2003), 586-606. http://dx.doi.org/10.1111/1540-6210.00322

Brewer, G. A., \& Selden, S. C. (2000). Why Elephants Gallop: Assessing and Predicting Organizational Performance in Federal Agencies. Journal of Public Administration Research \& Theory, 10(4), 685-711. http://dx.doi.org/10.1093/oxfordjournals.jpart.a024287

Central Bank of Nigeria Statistical Bulletin. Vol.20 Dec. 2010.

Chartered Institute of Management Accountants. (2009). IFAC recommendations to G20 in Response to the Global Financial Crisis.

Cheung, J., \& Krishnan, G. (1997). Does Inter-period Tax Allocation Enhance Prediction of Cash Flows. Accounting Horizons, 11(4), 1-15.

Costanza, R., Hart, M., Posner, S., \& Talberth, J. (2009). Beyond GDP: The Need for New Measures of Progress. The PARDEE PAPERS / No. 4 / January 2009, Boston University Creative Services, Trustees of Boston University.

Damian P. (2011). Treasury Crafts a Plan: Who Gets Paid, Who Doesn't. The Wall Street Journal.

Retrieved

from http:/online.wsj.com/article/SB10001424053111903635604576472500261491910.html. 
David, N. A. (2007). Performance Measurement: A Tool for Accountability and Performance Improvement. County and Municipal Government in North Carolina, Article 16. UNC-Chapel Hill School of Government.

Dechow, P. M., Hutton, A. P., Kim, J. H., \& Sloan, R. G. (2011). Detecting Earnings Management: A New Approach. The Haas School of Business University of California, Berkeley, CA 94705 and Carroll School of Management Boston College.

Government Accountability Office. (2011). Debt Limit: Delay Creates Debt Management Challenges and Increase Uncertainty in the Treasury Market. http:/www.gao.gov/products/GAO-11-203.

Greenburg, R., Johnson, G., \& Ramesh, K. (1986). Earnings versus Cash Flows as a Predictor of Future Cash Flow Measures. Journal of Accounting, Auditing \& Finance, 1(4), 266-277.

Jeroen C.J.M. van den Bergh. (2009). The GDP paradox. Journal of Economic Psychology, 30, 117-135. http://dx.doi.org/10.1016/j.joep.2008.12.001

Jordan, C. E., Waldron, M. A., \& Clark, S. J. (2007). An Analysis of the Comparative Predictive Abilities of Operating Cash Flows, Earnings, and Sales. The Journal of Applied Business Research, 23(3).

Kalyan City Life Archive. (2012). Research by Manoj Patil. Updated Maintained by Gaurav Akrani, SEO and Redesigned byBhuvan Shah.

Lorek, K., \& Willinger, G. (1996). A Multivariate Time-Series Prediction Model for Cash Flow Data. The Accounting Review, 71(1), 81-101.

Louise R. (2011). Public Sector Performance: A Global Perspective Chartered Institute of Management Accountants.

Lukas S., \& John P. S. (2009). Defining Performance in Public Management Variations Over Time and Space. Paper for IRSPM XXIII, Copenhagen, 6 - 8 April 2009.

Mackay, K. (1998). Public Sector Performance-The Critical Role of Evaluation. World Bank Operations Evaluation Department Evaluation Capacity Development.

Mayhew, S. (2009). Oxford Dictionary of Geography. Oxford University Press

McBeth, K. (1993). Forecasting Operating Cash Flow: Evidence on the Comparative Predictive Abilities of Net Income and Operating Cash Flow from Actual Cash Flow Data. The Mid-Atlantic Journal of Business, 29(2), 173-187.

Messaoud, H. (1999). Statistics on Public Sector Employment: Methodology, Structures and Trends. Bureau of Statistics, ILO Geneva Working Paper SAP2.85/WP.144.

Murdoch, B., \& Krause, P. (1989). An Empirical Investigation of the Predictive Power of Accrual and Cash Flow Data in Forecasting Operating Cash Flow. Akron Business and Economic Review, 20(3), 100-113. 
Natural Resources Management and Environment Department. (2003). Agricultural Extension, Rural Development and the Food Security: Public Sector Agricultural Extension Challenge FAO Corporate Document Repository.

Ndan J. D. (2007). Public Finance: A Nigerian Perspective. Faith Printers Zaria.

Neter J., \& W. Wasserman, W. (1974). Applied Linear Statistical Models, Richard D. Irwin, Inc., Homewood, Illinois.

New Zealand Government. (2010). Public Sector Communications Function.

Ofem, B. I. (2012). A Review of the Criteria for Defining Urban Areas in Nigeria. (C) Kamla-Raj 2012 J Hum Ecol, 37(3): 167-171 (2012) Department of Urban and Regional Planning, University of Uyo, Uyo, Nigeria E-mail: beulahikpi@yahoo.com.

Pricewaterhouse Coopers. (2008). How Principles-Based Risk Assessment Enables Organizations to take the Right Risks, A practical Guide to Risk Assessment.

Sahaj, I. J. (2001). Public Sector Budgetary Performance Results of the Slovak Republic For the year 2001. National Bank of Slovakia.

Sheriffdeen A. T. (2012). The Nigerian 2012 Budget: A Critical Appraisal. Department of Economics, Banking and Finance, Babcock University, Ogun, Nigeria. Central Bank of Nigeria Statistical Bulletin.

Silva, L. M. D., \& Jayamaha, A. (2012). Budgetary Process and Organizational Performance of Apparel Industry in Sri Lanka. Journal of Emerging Trends in Economics and Management Sciences (JETEM) 3(4), 354-360

The Institute of Public Administration of Canada (IPAC): Performance Measurement. Leadership Matters Topical Briefs.

The Organisation for Economic Co-operation and Development (OECD: Government at a Glance 2011, OECD.

US Department of the Treasury. (2011). Get the Facts: Raising the Debt Limit. Retrieved from http://www.treasury.gov/press-centre/news/Pages/debt-limit.aspx 